\title{
Justice in Hobbes' and Rawls' Ideologies and the Quest for Social Order in Africa: A Philosophical Reflection
}

\author{
Ujomu, Philip Ogo 1 \\ University of Benin, Benin-City, Nigeria \\ Olatunji, Felix Olusanjo \\ Ladoke Akintola University of Technology, Ogbomoso, Nigeria
}

\section{Introduction}

Some views of justice mainly the social contract model of Thomas Hobbes, and the fairness model of Rawls may have failed to challenge and overcome the peculiar ideological and value-laden character of an African environment, thus creating the impetus for reconsideration. The social contract model of justice assumed that there would be justice when people acting as rational agents accepted basic practices of society that would assure their mutual advantage in the long run. The impartiality or fairness model of justice, suggests the recognition of the intrinsic worth of people as entities deserving of respect, whose interests should be maintained in the interest of the overall common good. How do these theories apply to the African condition? These issues will be the thrust of this paper as we argue that the two models are not enough in solving the multifarious problems that Africa finds herself. These will be examined succinctly in arguing for the latent solution towards a sustainable social order that considers and puts everyone and the society towards attaining justice and development.

The idea of Hobbes was based on the conception of justice as mutual advantage. This theory holds that the function of justice is to construct social devices that enable people who are essentially egoists to get along better with one another (Nielsen, 1996:86-87). Thus within the egoistic framework of life, the reason for justice is the pursuit of individual advantage. In other words, given that limited resources and conflicting interests characterised human life then people can expect

${ }^{1}$ Lead Author 
to further or promote their interests, if they live harmoniously with others in the society (Nielsen, 1996:86-87). Therefore, justice emerges here, as "a set of minimal constraints necessary for achieving social coexistence, co-operation and well being" (Nielsen, 1996:86-87). This conception of life concedes that there is a need for justice understood among others as the basis of productive human cooperation.

Besides, Rawls engages the utilitarian position by further pointing out its grievous defects. In responding to classical utilitarianism, he brings up the idea of justice as fairness, based on a contractarian conception of reality. According to him, "each person possesses an inviolability founded on justice that even the welfare of society as a whole cannot over-ride. For this reason, justice denies that the loss of freedom for some is made right by a greater good shared by others" (Rawls 1972:3-4). He argues further that "when the principle of utility is satisfied, however, there is no assurance that everyone benefits" (Rawls 1972:177). What then are Rawls principles of justice, and what do they signify?

\section{Hobbesian Justice and its Short-falls: Rethinking the Unending State of Nature as Anarchy or Servitude}

Within this western Modernist account, we can appreciate a theoretician of justice such as Thomas Hobbes, who insisted on the concept of justice within the ambits of the idea of the Leviathan. The Leviathan retains immense and illimitable powers over men and materials and is thus capable of guaranteeing justice. Hobbes made it clear that the conception of justice and security offered by the Leviathan became imperative due to the low life expectancy, ominous danger and insecurity of life and possessions in the state of nature. Central to the imperative of justice in Hobbes is the appreciation of the circumstances real and imagined prevailing in the state of nature. Hobbes traces the emergence of the Leviathan to the nature of man and the conditions of the state of nature. He says that nature has made men equal in the faculties of the body and mind. Despite that there are differences in the way men are endowed with these faculties; these differences are not so considerable as to allow one man certain qualities that others do not have. For him, this equality of ability among men gives rise to the equality of hope or the belief that all have the same chances of attaining their ends. This equality gives rise to disputes over the resources of nature, in which people exercise their powers in order to conquer, dispossess or deprive weaker ones of their lives, liberties and properties. Therefore, Hobbes contends that the equality of men gives rise to a condition of mutual 
destruction in which no man can be sure of emerging victorious or subsisting for a reasonable length of time (Hobbes 1963:142).

According to Hobbes, that period of human existence when men live without a common power to control them all or arbitrate among them is called "the state of war" (Hobbes 1963:143). In this state, every man is against every man. Hobbes takes care to point out that this state of war encompasses not just conditions of actual conflict, but also the state of existence in which men are disposed to behave as if they are in a state of war. Furthermore, in the state of nature or war where every man is every man's enemy and the security and protection of life and property is not assured, there is no industry or fruitful labour. And other human activities like culture, art and society do not exist. For Hobbes, the state of nature is the state of war. It is the state of the violence and anarchy of every one against the other. This condition of life is typified by the inability to guarantee survival and peace for any reasonable length of time. One of the most distinctive features of the state of nature is the fact that it does not guarantee the individual or aggregate of interests except there is a normative exit using the facilities of a contract. Hobbes informs us that it is absolutely important to note that "to this war of every man against every man, this also is consequent; that nothing can be unjust. The notions of right and wrong, justice and injustice have there no place. Where there is no common power, there is no law: where no law, no injustice" (Hobbes 1968:188). The outright repercussion of this is that "in such a condition, every man has a right to every thing; and therefore, as long as this naturall right of every man to every thing endureth, there can be no security to any man, (how strong or wise soever he be)" (Hobbes 1991:110).

But this is not all about the state of nature. Hobbes informs us that "worst of all, there is a continual fear and danger of violent death. In short, the life of man is solitary, poor, nasty, brutish and short" (Hobbes 1963:143). Against the background of the absence of a common power, law, notions of justice and injustice, right and wrong in the state of nature, Hobbes says that the passions and the reason of man lead him to search for peace. Man's quest for peace arises from his fear of death, and his desire for those resources necessary for adequate living. By desiring peace and co-operation, man uses reason to fashion some convenient articles of peace out of the right and law of nature. According to Hobbes, the right of nature is the liberty that all men have to use their powers to preserve their lives, while the law of nature is a general rule derived from reason, which forbids a man to destroy his life or the means of preserving his life. For Hobbes, the first and 
basic law of nature is to seek peace, while the second law of nature enjoins a man to readily give up his right to self-defence if others show a willingness to do likewise.

He notes that a man gives up his right to self-preservation either by renouncing or transferring it. A right is renounced when one does not care to whom the benefit goes, while a right is transferred when one intends that the benefit goes to some specified persons. Hobbes maintains that the acts of rights' renunciation or transfer are conducted through declarations and transactions binding the participants to a term of agreement. The goal of rights' transfer is the guarantee of security of life and the means of preserving life. In effect, the realisation of the short-falls of the state of nature would pave the way for the emergence of the commonwealth. According to Hobbes, social order as the great Leviathan, commonwealth, state is an artificial man created to protect and defend the natural man. He says that "the sovereignty of the Leviathan is its artificial soul, which gives life and animation to the whole body" (Hobbes 1963:139). In his view, the Leviathan's strength lies in the wealth and riches of all its members. And every part or member of the Leviathan is induced to perform his duties by the sovereign who has the power to punish or reward.

For Hobbes, contract is the name given to the mutual transfer of rights among men. It is the basis of the commonwealth, which exists in order to ensure that lives are preserved and made happy. The protection of life and property is guaranteed in the commonwealth, only when men erect a common power on which they confer all their powers and strengths. Hobbes notes that "this common power can be one man or an assembly of men" (Hobbes 1963:148). The commonwealth is attained through the processes of the transfer and renunciation of the rights of man and the laws of nature. The commonwealth emerges from the debris of the state of nature that was defeated by the superior logic and opportunistic inclination of men. The commonwealth, according to Hobbes, is the only source of security both from human nature, natural forces and other material creations of men. The commonwealth is the aggregation of an institutional arrangement of a multitude that has covenanted through the social contract to form and live in the society in order to assure themselves of mutual defence, peace, progress and protection from internal and external dangers. The power of the sovereign, conceived as either the ruler or the society, is central to attaining justice and security. 


\section{Rawls' Notion of Justice and its Weaknesses: Ideological Neutrality as Ambivalence or Formalism}

Rawls justified his position using a broadly Kantian contractarian view-point. According to Rawls, "the principles of justice are also categorical imperatives in Kant's sense. For by a categorical imperative, Kant understands a principle of conduct that applies to a person in virtue of his nature as a free and equal rational being (Rawls, 1972:253). Rawls tries to provide what he considers to be a model of social order based on a conceptualisation of justice. His ideas tilt towards the redistribution of wealth and opportunities typical of social democratic theorising. For Rawls, the identity and conflict of interest that illustrate life in any society marked by social co-operation, collaboration and distribution, necessitate the existence of a set of principles. He says that these principles are to guide our choice among the various social arrangements, which determines the division of advantages and for under-writing an agreement on the proper distributive shares. Thus, Rawls goes ahead to defend his two principles of justice on the ground that "the public recognition of the two principles gives greater support to men's self respect and this in turn increases the effectiveness of social cooperation. Another way of putting this is to say that the principles of justice manifest in the basic structure of society men's desire to treat one another not as means but only as ends in themselves" (Rawls 1972:178-179).

For Rawls, in a contemporary account, "justice is a set of principles required for choosing among the various social arrangements, which determine the division of advantages and for underwriting an agreement on the proper distributive shares. These principles are the principles of social justice, they provide a way of assigning rights and duties in the basic institutions of society and they define the appropriate distribution of the benefits and burdens of social cooperation" (Rawls 1971:4). Rawls insists that a society is well ordered only when it is designed to advance the good of its members and also effectively regulate its operation by a public conception of justice. He holds that "the primary subject of justice is the basic structure of society or more exactly, the way in which the major social institutions distribute fundamental rights and duties and determine the division of advantages from social co-operation" (Rawls 1971:7). Moreover, the justice of a social scheme depends mainly on the principles of justice, which free and rational persons concerned to advance or promote their personal interests would accept in an initial position of equality. 
Rawls says that the original position of equality corresponds to the state of nature in the traditional theory of the social contract. Understood as a purely hypothetical situation, Rawls argues that the original position is essentially about the fact that "no one knows his place in society, his class position or social status, nor does anyone know his fortune in the distribution of natural assets and abilities, his intelligence, strength, etc." (Rawls, 1971:13). Rawls assumes also that the parties in the original position do not even known their conceptions of the good or their special psychological attitudes and inclinations. Rawls' idea of justice as fairness emphasises on the procedures by which rights and duties can be determined and allocated in ways that ensure fair distribution of advantages and benefits (Solomon and Greene 1999:426\&435). To this effect, Rawls highlights the idea that the human being's starting point in life is a matter of chance. Hence, Rawls places all choices behind the veil of ignorance, which aims at ensuring that no one is advantaged or disadvantaged in the choice, due to circumstances or chance. Hence, the veil of ignorance describes the operations of the original position in which individuals do not retain any prior knowledge or advantage that can unduly affect their choice of the principles of justice. To the extent that the principles of justice are chosen behind a veil of ignorance, the intention of Rawls is to guarantee that no one is disadvantaged or advantaged in the choice of principles, either by the outcome of natural chance, or the contingency of social circumstances.

According to Rawls, persons in the initial situation would choose two principles. "The first requires equality in the assignment of basic rights and duties. While the second holds that social and economic inequalities for example, those of wealth and opportunity are just, only if, they result in compensating benefits for everyone and in particular for the least advantaged members of society" (Rawls, 1971:14). In other words, Rawls proposes two principles of justice: "Firstly, each person is to have an equal right to the most extensive total system of equal basic liberties compatible with a similar system of liberty for all. Secondly, social and economic inequalities are to be arranged so that they are both: (a) to the greatest benefit of the least advantaged and (b) attached to offices and positions open to all under conditions of fair equality of opportunity"(Buchanan, 1980:9). Thus, Rawls proposes the greatest equal liberty principle, the difference principle and the fair equality of opportunity principle. Rawls first principle covers basic liberties for instance, the freedom and right to vote, freedom of speech, and of the press, freedom of the persons. His second principle requires that the basic structure be arranged such that any inequalities in prospects of obtaining the primary goods 
(wealth, income, power) must work to the greatest benefit of the least advantaged in the society. His principle of fair equality of opportunity demands a movement beyond formal equality of opportunity to ensuring that those with similar skills, abilities and motivation, enjoy equal opportunities (Buchanan, 1980:9-12).

\section{A Critique of These Views vis-a-vis Dominant African Cultural Forms of Life}

The apparent failure of erstwhile classical philosophies of justice for African development and social order to counteract discriminative moral and political conduct elicit a dilemmatic situation. A traditional Western conceptualisation (DeMarco and Richmond, 1977:86) of the philosophy of justice is centred on an analysis of the social contract model of Thomas Hobbes and the fairness model of John Rawls. These models among others have failed to challenge and overcome the peculiar African crises of justice and development. These traditional western philosophies have not succeeded in Africa due to obstructive traditional templates that have re-institutionalised regressive authoritarianism, tenuous hegemony, anachronism deriving from both the primordial and colonial forms of ethnoreligious prejudices, conflicts, mistrust and mutual xenophobia among groups. In traditional African cosmology, justice and human relations principles are a key component of culture. The idea of justice practised by the Africans is to be seen in their age-long activities that depended on robust sense of social or ethnic identity. This kind of justice was often kinship in nature operating on internal familial principles of intense human homogenous co-existence. In a sense, the African cosmological justice was one that operated in a community of people bonded by kinship and familial ties, and thus could not operate on the impersonal and impartial laws. Due to the smallness and knit character of the traditional African communities, kinship justice connoted a concern for attending to the actual interests of every member, such that the good was seen as the well being of the entire society and not of the majority nor of an individual. The ontological bonding typical of justice in a knit community did not allow for any demonstration of the trappings and chaos typical of the state of nature. It is clear that the core western conceptions of the justice idea may not have easily fitted into the African cosmological models. The concrete reality of the western ideas shows a commitment to values that may not easily work in the African spaces. Social interest imperatives underlie the foundations of justice and effectively make the discourse on justice a cultural or context bound event.

The social contract model of justice assumed that there would be justice when 
people acting as rational agents accepted basic practices of society that would assure their mutual advantage in the long run. This has not really worked in African development practice, due to the nullifying effects of kleptocracy, patrimonialism, cult of personality in power relations, institutional decay, antinomies and apathy, precipitation of primordial ethno-cultural enclaves. Defining the impartiality or respect model of justice, which suggests the recognition of the intrinsic worth of people as entities deserving of respect, whose interests should be maintained equitably in the interest of the overall common good, have also failed due to the realities of cultural, historical and psychological inducements to truncate or restrictively appropriate the principles and institutions intended for the common good; federalism, industrialisation and social services.

The appealing, systematic and well-articulated justice theory of Hobbes suffered from certain internal contradictions. It did not fully account for the dangers arising from the illimitable powers that were bestowed on the sovereign as ruler. Hobbes did not reckon with the fact that these powers would pave the way for dictatorship, primitive accumulation, misappropriation, authoritarianism and the eventual denial of the same justice and security of lives and property. It was this unresolved paradox of justice and security that other theoreticians tried to address. Hobbesian idea of justice fails in so far as the individualistic rational egoism that led to the emergence of the state or society has created a state that now unleashes the very injustice or non-justice situation that the state was supposed to arrest or modify. What this means, is that the application of Hobbes theory of justice to Africa may not work not only due to the nullifying injustices perpetrated by the state, but also due to the fact it refuses to recognise the communalist non-individualist ontology or basis of the African societies. In modern Africa, the Hobbesian model of justice refuses to foster the definitive distinction between the state of nature and the state itself. The core visions and values of the state in Africa, is to persecute, terrorise and subjugate the mass of Africans. The real tragedy of an inclusive communalism grafted on a modern individualist perception of reality occasions a crisis of identity and national planning that turns virtually every institution or structure into a vector of injustice. The real failure of state machineries such as the police, military, census and education can be tied to the irreconcilable contradictions arising from the desire to communalise and ethnicise individualistic mechanisms designed for social order and change. The communal factor, therefore, becomes the currency that nullifies the play of individualism as a directing principle.

It should not be forgotten that Rawls theory is individualistic though it recognises 
the least advantaged (Manicas, 1981:279). This is the character of a liberal theory of justice that stands in contradistinction to that of Africa to the extent that it is based on "the vision of society as made up of independent autonomous units who co-operate to further the end of each of the parties; which vision Rawls presses to its logical limit by deriving the principles of justice themselves from a notional social contract" (Flew, 1976:75). Let us not forget that "contractarian theories are undermined when it is shown that they favour a particular model of society" (Eshete, 1975:40). This view of justice is in the first instance, restrictive both from an African exogenous view-point and from a parallel western view-point of Marxian theorising. Engels and Marx apparently concur on the "total condemnation of justice-talk as mere ideology, and consequently, justice seems never to mean anything more than "justice within a particular socio-economic system." There was feudal justice and there is bourgeoisie justice" (McBride, 1975:205). Under such arrangement, Husami (1978:33) insists that "the distributive arrangements of a society can be evaluated by means of a standard different from the prevailing (or ruling) standard of justice."

\section{Human Nature and Ethnicity as Principles of Social Control in Africa}

In looking at the mechanism of social control that both embodies and underlies ethnicity we cannot but examine what ethnic groups are, what are those things that make ethnic groups distinct? What are the manifestations of ethnicity and how do these become consequential for human social and political existence whether positively or negatively? The popular conception of ethnicity is that which highlights its prominent negative aspects. Odugbemi (2001) makes it clear that "ethnicity undermines the fundamental values without which we cannot build a sane, serious, democratic society" (2001:70). Galey holds that the processes of culture that define ethnicity may also influence citizenship attitudes to development and integration in a national context (1974:270). These cultural processes and influences are, therefore, essentially cognitive and transmittable. Ethnicity becomes potent because living styles, values and behaviour are cognitively acquired and transmitted to new generations through social institutions such as family and tribe. These may encourage resistance and/or openness to change (Galey, 1974:270), which either relates to the self or even others.

There are a number of values and visions that ethnicity transmits, which make it a force that is self-animating and equally countermanding to dominant modernising instruments such as the state, etc. Ethnicity transmits specific views of economic 
relations, loyalty, identity, etc. Clapham holds that ethnicity is a very effective basis for mobilising political support and family and kinship ties provide more reliable means of achieving loyalty than the state and its bureaucracy (1991:98). This situation obviously has profound consequences for establishing and sustaining community and consensus. Goulbourne notes that the mobilisation around ethnic credentials as seen in the operations of minorities or majorities, depends significantly on the political and economic circumstances that define inter-group relations. Thus the mobilisation of ethnicity entails the mobilisation of bias (1997:166). Also Lemarchand says that the over-whelming aim of ethnicity is its focus on exclusion of others from power. The ensuing contexts and struggles for control have decisive negative impacts on patron-client relationships, inter ethnic identities (1974:143). Such convolutions in social organisation and psychological pre-dispositions simply replace the question of human survival on the centre stage. Ethnicity compels us to place the issue of human well-being and survival on the front burner then we have to understand the motivations and compulsions of human nature.

Human nature is a critical aspect of human existence. Berry (1986:xiii) insists that "social and political organisation has to accommodate itself to the human nature and not vice versa." In other words, human nature is a primal symbol in the quest for understanding ethnicity. This is a conceptual issue having far reaching empirical consequences. Dewey makes the vital point that the nearly immutable innate needs of human beings define human nature that:

I do not think it can be shown that the innate needs of men have changed since man became man or that there is any evidence that they will change as long as man is on the earth. Needs for food and drink and for moving about, need for bringing one's power to bear upon surrounding conditions, the need for some sort of aesthetic expression and satisfaction, are so much part of our being. Pugnacity and fear are native elements of human nature. But so are pity and sympathy (1974:116-118).

The foundational character of human nature is to be apprehended and connected to what Mill refers to as the natural sentiment of justice, which is defined by the 
interplay of the purportedly innate ideas of punishment, self-defence and sympathy. Mill states that:

two essential ingredients in the sentiment of justice are, the desire to punish a person who has done harm, and the knowledge or belief that there is some definite individual or individuals to whom harm has been done. The desire to punish ...is a spontaneous outgrowth from two sentiments, both in the highest degree natural, and which either are or resemble instincts; the impulse of self-defense, and the feeling of sympathy. A human being is capable of apprehending a community of interest between himself and the human society of which he forms a part such that any conduct, which threatens the security of the society generally, is threatening to his own and calls forth his instinct of self-defense (1962:306-307).

Human nature and its significance for survival and progress make further sense only in the context of the social nature of man. According to Mackenzie (1963:35), "human association, societies are first formed for the sake of life; though it is for the sake of good life that they are subsequently maintained. The care of the young, the preservation of food and drink, the provision of adequate shelter and protection would suffice to account for the existence of human societies." This implies that society is necessary for some level of comfort and hope for the human being.

We also know from history that human associations have been the core sources of security problems. For example, there is the problem of tyranny and man's inhumanity to man, as seen in the internal operations of human actions in a society. There is the wider social insecurity generated by human inter-cultural conflicts among human associations. All of these problems can be predicated upon the personal and social manifestations of human nature and human actions. The clearly psychological, cultural and economic motivations of human nature are further highlighted in the problems of human finitude and limitations, seen as our ethical and metaphysical imperfections. We also confront the restrictive limitations of our peculiar human natures as individual men. And all of these taken together pose a stumbling block to our search for perfect human relations. Given the reality of 
conflicts and prejudices, Brown (1989:3) says that ethnic conflicts can be explained using the natural tendency towards ethnocentrism: people seem to trust and prefer those of their own cultural group, while being distant and distrusting of others.

The increasing tendency of ethnic people to think fundamentally in terms of the ethnic group (Said and Simmons, 1975:65) leads to the real threat of mutual annihilation or the massive repression of the less-privileged and competitors. We can understand the full import of things, when we read and see that ethnicity has led to state-sponsored slaughter, the oppression and murder (Riggs, 1994:584); unparalleled cultural diversity heralding constant conflict and bloodshed (Campbell, 1992:58) and sentiments motivating people to acts of extreme violence against the other (Turton, 1997:3). For Turton (1997:11), ethnicity has a strong mobilising power to acquire greater leverage and competitive advantage. Thus ethnicity often gives rise to ethnic conflicts in which people decide to employ their ethnic differences in pursuing competing interests (Osaghae, 1994:9). The end result of all of this according to Rosel is that ethnic conflicts have become politicised and radicalised thus assuming a self-sustaining character, which threatens the legitimacy and integrity of multi-ethnic states. Through the politicisation and militarisation of ethnic conflict, groups acquire the selfawareness and organisation, cohesion and bitterness and finally, intransigence and cynicism, which make a peaceful and enduring resolution or settlement difficult to negotiate (1997:146\&153).

\section{Conclusion}

We have argued in this paper that the real tragedy of an inclusive communalism grafted on a modern individualist perception of reality occasions a crisis of identity and national planning that turns virtually every institution or structure into a vector of injustice in Africa. And the main reason why these models - Hobbes and Rawls among others - have failed to challenge and overcome the peculiar African crises of justice and development. These traditional western philosophies have not succeeded in Africa due to obstructive traditional templates that have reinstitutionalised regressive authoritarianism, tenuous hegemony, anachronism deriving from both the primordial and colonial forms of ethno-religious prejudices, conflicts, mistrust and mutual xenophobia among groups. The Hobbesian model of justice refuses to foster the definitive distinction between the state of nature and the 
state itself while Rawls' argument also projects the individual even though there is the tendency towards the least-off in the society.

Our argument in the quest for social order is that of looking at the discourse of ethnicity and human nature as the approaches towards social control, resuscitation and reconstruction. This situation obviously has profound consequences for establishing and sustaining community and consensus and it is a critical aspect of human existence as it is a significant part towards survival and progress, which makes sense only in the context of the social nature of man

\section{References and notes:}

Berry Christopher J., $\quad$ 1986, Human Nature (London: Macmillan Education Ltd).

Brown David., 1989, "Ethnic Revival: perspectives on state and society". Third World Quarterly. vol. 11. No.4. pp. $1-17$.

Buchanan, Alex 'A Critical Introduction to Rawls Theory of Justice' in John Rawls Theory of Social Justice. An Introduction edited by Gene Blocker and E. H. Smith. Athens: Ohio University Press, 1980.

Clapham, Christopher., 1991, "The African State” In D. Rimmer (Ed). Africa, Thirty Years On. London: James Currey. pp. 91-104.

Demarco Joseph P. and Richmond Samuel P., (1977), "equality and justice" Dialogue vol.10. no. 2. pp.85-88.

Dewey, John (1974) "Does Human Nature Change?" in Bronstein, Daniel, Krikorian, Yervant, Wiener, Philip, (edited) Basic Problems of Philosophy $3^{\text {rd }}$ Edition. New Jersey: Prentice-Hall, Inc. Pp. 116-121.

Eshete Andreas (1975) "Contractarianism and the scope of justice" Ethics. Vol. 85. pp. 3849.

Flew Anthony, (1976)., "A theory of social justice” in H.D. Lewis (ed) Contemporary British Philosophy. London: George Allen and Unwin. Pp.69-85.

Galey, Margaret., 1974, "Effects of Ethnic Conflict on National Development. A Commentary" Wendel Bell \& Walter Freeman (Ed) Ethnicity and Nation - Building: Comparative International and Historical Perspectives. London: Sage Publications. Pp. $269-279$.

Goulbourne, Harry., 1997, "Ethnic Mobilization and Multiculturalism" in David Turton War and Ethnicity. Global Connections and Local Violence (Ed) New York: University of Rochester Press. Pp. 163 - 177.

Hobbes Thomas., (1963), Leviathan in Social And Political Philosophy (Edited) By J. Somerville et al New York: Anchor Books.

Hobbes Thomas., (1968), Leviathan England: Penguin

Hobbes Thomas (1991) "Thomas Hobbes" in Clarence Thomas (ed) The Great Legal Philosophers (Philadelphia: University of Pennsylvania Press).pp. 107-133.

Husami Ziyad I. (1978)., "Marx on Distributive Justice" Philosophy and Public affairs. Vol.8.no.1. Pp. 27-64.

Johnson Curtis (1985) “Thrasymachan Justice” Durham University Journal (December) Vol. LXXVIII. No.1. Pp. 37-49. 
Kant, Immanuel., (1965), The metaphysical elements of justice. Part 1 of the metaphysics of morals. John Ladd Trans. edited Indianapolis: Bobbs-Merrill

Kant, Immanuel (1990)The Science of Right trans Hastie Great Books of the Western World vol. 39 (edited) Alder M. J. Chicago Encyclopedia Britannica Inc)

Kant Immanuel (1991) "Immanuel Kant" in Clarence Thomas (ed) The Great Legal Philosophers. (Philadelphia: university of Pennsylvania press).pp. 237-260.

Kant, Immanuel (1996) Grounding for the Metaphysics of Morals R. Larmer (ed) Ethics in the Workplace: Selected Readings in Business Ethics (Minneapolis West Publishing Company). Pp. 40-43.

Korsgaard Christine (1989)., "Kant” in Robert J. Cavalier, James Gouinlock, James P. Sterba Ethics in the History of western Philosophy London: Macmillan.

Kristol Irving ., (1977), "liberty and economics" Dialogue vol.10. no. 2. pp.95-97.

Kupperman, Joel., (1983), The Foundations of Morality (London: Unwin).

Laing B.M (1933) “The Problem of Justice in Plato's Republic” Philosophy. Volume. VIII. Number 32. (October). Pp.412-421.

Lemarchand, Rene., 1974, "Status Differences and Ethnic Conflict: Rwanda and Burundi" Wendel Bell \& Walter Freeman (Ed) Ethnicity and Nation - Building: Comparative International and Historical Perspectives. London: Sage Publications. Pp. 135 - 146.

Mackenzie, J. S., (1963), Outlines Of Social Philosophy London: George Allen \& Unwin.

Manicas, Peter. T. (1981) 'John Dewey and The Problem of Justice' Journal of Value Inquiry. Vol. 15. No. 4. Pp. $279-291$.

McBride Leon., (1975)., "the concept of justice in Marx, Engels and others" ethics. Pp. 204-218.

Mill J.S., (1962), Utilitarianism, On Liberty, Essay on Bentham edited by Mary Warnock. (Great Britain: William Collins).

Mill J.S., (1975), Utilitarianism, On Liberty, Essay on Bentham edited by Mary Warnock. (Great Britain: William Collins).

Mill, J.S (1990) On Liberty Representative Government Utilitarianism Great Books of The Western World, Vol. 40 (Edited) M.J Alder (Chicago: Encyclopedia Britannica Inc).

Mill John Stuart (1991) "John Stuart Mill” in Clarence Thomas (ed) The Great Legal Philosophers. (Philadelphia: university of Pennsylvania press).pp.364-393.

Nielsen, Kai (1996) “Conceptions of Justice” In Mary Hawkesworth (Ed) Encyclopedia of Government and Politics Volume 1 (London: Routledge).

Odugbemi Sina., 2001, "Ethnic nationalism and the future of Nigeria" RECALL. No.2. (January). pp. 66-75.

Osaghae, Eghosa (1994) Ethnicity and Its Management in Africa: The Democratization link. Lagos: Malthouse Press.

Rawls, John (1971) A Theory of Justice (Oxford: Clarendon)

Rawls, John (1972) A Theory of Justice (Oxford: Clarendon)

Riggs, Fred., 1994, "Ethno Nationalism, Industrialism, And The Modern State" Third World Quarterly Vol. 15, No. 4. pp. 583-611.

Rosel Jakob., 1997, "Nationalism and Ethnicity: Ethnic nationalism and the regulation of ethnic conflict" in David Turton (ed) War and Ethnicity: Global connections and Local Violence. New York: University of Rochester Press. pp.145-161.

Said Abdul \& Simmons Luiz., 1975, "The Ethnic Factor in World Politics" Society Vol. 12, No. 2, (January/February). pp. 65-74.

Solomon Robert and Greene Jeniffer., (1999), Morality and the Good Life (New York McGraw-Hill College). 
Turton, David., 1997, “Introduction" in David Turton (1997) War and Ethnicity. Global Connections and Local Violence. (Ed) New York: University of Rochester Press. Pp: $1-45$

\title{
SUMMARY
}

\section{Justice in Hobbes' and Rawls' Ideologies and the Quest for Social Order in Africa: A Philosophical Reflection}

\author{
Ujomu, Philip Ogo \\ University of Benin, Benin-City, Nigeria \\ Olatunji, Felix Olusanjo \\ Ladoke Akintola University of Technology, Ogbomoso, Nigeria
}

\begin{abstract}
Divergent opinions and theories have been propounded towards attaining social order in human society as most of those theories are believed to have significant positive effects on the restructuring and reconstruction of society. This is done in the struggle for society devoid of manipulations, deceit, injustice, inequality among other problems confronting man in his relation to others around him. It should be pointed out from the outset that Thomas Hobbes' theory on the Leviathan and that of John Rawls' argument for justice as fairness are seen as significant in the reconstruction of the society and stand out among other models/theories. Hence, the essence of this paper is using the platform of these two theorists to argue for the reconstruction of justice and development in African society. This shall be dealt with to in putting across the pit-falls and the inadequacies of the theories to Africa predicaments.
\end{abstract}

Key Words: Social order, social justice, African society, inclusive communism 